\title{
The effect of COVID-19 on operating costs: the perspective of hotel managers in Antalya, Turkey
}

\section{O efeito da COVID-19 nos custos operacionais: a perspetiva dos gerentes de hotéis em Antalya, Turquia}

\section{Kaplan Ugurlu}

Kirklareli University, Turkey, kugurlu@superonline.com

\author{
Bayram Akay \\ Burdur Mehmet Akif Ersoy University, Turkey, bakay@mehmetakif.edu.tr \\ Sevda Demirel \\ Burdur Mehmet Akif Ersoy University, Turkey, dsevda750@gmail.com
}

Received: 09.06.2021; Revisions required: 14.10.2021; Accepted: 15.12.2021

\begin{abstract}
This paper aims to determine whether coronavirus (COVID-19) causes cost increases in accommodation enterprises and, if any, what these costs are. Additionally, executive perspectives were taken on operational budgets for 2020, occupancy rates, profitability, the decision to stay on or off, and expectations for the following year. The case study employed a qualitative research method, a multiple caseholistic design, and semi-structured interviews to elicit data. The data were collected from ten hotel managers in four- and five-star hotels in Kemer, Antalya, and serve as a sample for the study. COVID-19 has revealed the costs associated with hotel security and health measures, hygiene and cleanliness, and technological tools. Apart from these, legal restrictions have reduced the tourism season in hotel businesses from eight to four months. Business occupancy rates remained between 4560 per cent. Additionally, there was a $60 \%$ negative deviation in the enterprises' budget targets. Hotel managers were more concerned with achieving breakeven, keeping staff employed, and maintaining the hotel's image than with achieving the expected profit.
\end{abstract}

Keywords: COVID-19, operating costs, effect of COVID-19, hotel managers, Antalya.

\section{Resumo}

Este artigo tem como objetivo determinar se o coronavírus (COVID-19) causa aumento de custos nas empresas de alojamento e, em caso positivo, quais são esses custos. Para além disso, foram consideradas as perspetivas executivas sobre os orçamentos operacionais para 2020, as taxas de ocupação, a rentabilidade, a decisão de permanecer fechado ou aberto e as expectativas para o ano seguinte. $O$ estudo de caso utilizou um método de pesquisa qualitativa, um desenho múltiplo de casos holísticos e entrevistas semiestruturadas para a obtenção de dados. Foram entrevistados dez gerentes de hotéis de quatro e cinco estrelas em Kemer, Antalya. A COVID-19 revelou os custos associados à segurança dos hotéis, medidas de saúde, higiene e limpeza e ferramentas tecnológicas. Além disso, as restrições legais reduziram a estação turística nos hotéis de oito para quatro meses. As taxas de ocupação permaneceram entre $45 \mathrm{e}$ $60 \%$. Além disso, houve um desvio negativo de $60 \%$ nas metas orçamentais das empresas. Os gerentes de hotéis estavam mais preocupados em alcançar um ponto de equilíbrio, manter o emprego dos funcionários e a imagem dos hotéis do que em alcançar os lucros esperados.

Palavras-chave: COVID-19, custos operacionais, efeito da COVID-19, gestores hoteleiros, Antalya.

\section{Introduction}

Coronavirus (COVID-19), which appeared in Wuhan, China in December 2019, soon turned into a pandemic. According to BBC News (2021), as of 30 March 2021, the number of cases of COVID-19 virus has exceeded 127.7 million worldwide, and the number of deaths has exceeded 2.7 million. In addition to the negative effects of the pandemic on human health, it had also negative effects on the national and the world economy. National and international flight cancellations, travel restrictions, and international tourism all come to a halt for a variety of reasons, including the fact that the tourism industry is the most economically impacted during the pandemic period (Gössling, Scott \& Hall, 2021; Gallego \& Font, 2020; Pavlatos, Kostakis \& Digkas, 2021; Gretzel et al., 2020; Galvani, Lew \& Perez, 2020). According to the UNWTO (2021), international tourism reached 1.5 billion tourists and $\$ 1.6$ trillion in revenue in 2019. In 2020, 381 million tourists earned $\$ 300$ billion in tourism earnings, and global tourism activity declined by $74 \%$. Turkey received $\$ 34.5$ billion in tourism earnings in 2019 from 51.7 million tourists. In 2020, the pandemic period, 15.9 million tourists generated $\$ 12.1$ billion in revenue. The number of

tourists fell by $70 \%$ and tourism earnings fell by $65 \%$ during the pandemic period (Ministry of Culture and Tourism, 2021b). As with any other aspect of life, safety is critical in tourism. Pandemics, such as terrorist attacks, natural catastrophes, and wars, significantly impact or even eliminate tourism. In such instances, travel suppliers have attempted to re-enter the business by diversifying their offerings. Due to pandemics like COVID-19, which pose a major risk to human life, travellers and travel suppliers have attempted to maintain a presence in the sector/market by shifting to safer preferred destinations (loannides \& Gyimóthy, 2020). While COVID-19 is altering people's travel behaviours, tourist businesses are finding it exceedingly difficult to adapt (Hall, Scott, and Gössling, 2020). If demand and supply make the required advances, tourism can undergo a transformation (Brauder, 2020).

Although the virus affects tourism movements that much, vaccination studies and the start of vaccination of people are so promising for many countries, including Turkey, that tourism movements can accelerate. However, during the COVID-19 process, significant costs were incurred to every tourism business, including hotels, restaurants, tour operators, travel 
agencies, souvenir businesses. The purpose of this study was to determine the cost of coronavirus (COVID-19) infection to accommodation businesses. Additionally, the study analysed the accommodation sector's budgets for 2020, occupancy rates, profitability, the decision to remain open or close, and expectations for the next year from the perspective of the managers of the accommodation facilities that participated in the survey. This study will contribute not just to filling a need in the academic literature, but also to providing practitioners with pertinent knowledge.

\section{Literature Review}

\subsection{Coronavirus (COVID-19)}

The World Health Organization named COVID-19 a global pandemic on March 11, 2020 (ATTA, 2020a). According to the definition made by the Turkish Ministry of Health, a family of viruses that can cause disease in humans and animals. This virus causes infections in humans, from the common cold to severe respiratory diseases such as MERS and SARS. It has been stated that coronavirus disease is caused by the SARS-CoV-2 virus (Ministry of Health, 2021). The coronavirus was defined as a new type of coronavirus (2019-nCoV) by the World Health Organization on 07.01.2020 and the name of the disease was determined as COVID-19 (ATTA, 2020a).

COVID-19 disease is found to pass without symptoms or affecting a person excessively, as well as serious symptoms such as high fever, cough, and difficulty breathing. At the stages where the disease is severe, it can lead to pneumonia, kidney failure, the patient's inability to breathe self-sufficient, and death. The disease is transmitted by inhaling respiratory droplets that occur when people carrying the virus cough, and by taking the hands to the eyes, mouth, and nose without washing after contact with environments with respiratory droplets (Ministry of Health, 2021). In COVID-19 disease, 80\% of people infected with the virus overcome the disease mildly, while $20 \%$ are treated in hospitals. COVID-19 disease affects more people over 60 years of age and people with chronic conditions (Ministry of Health, 2021).

According to information obtained from the COVID19 information site of the Turkish Ministry of Health (2021), the specific rules that we must follow to protect against COVID-19 disease are as follows:

- It is critical to keep your hands clean. They should be cleansed for 20 seconds with soap and water, but if there is no soap and water available, they should be cleaned with an alcohol-based cologne or disinfectant.

- Avoid touching our eyes, mouth, or nose without first washing or disinfecting our hands.

- Avoid contact with sick individuals who are infected with the virus.

- Hands should be washed with water and soap following direct contact with those who are infected or near those who are infected.
- When visiting medical institutions, contact with other patients should be minimized.

- Masks should be worn in crowded areas.

- In society, the social distance rule should be followed; a distance of one meter should be maintained between individuals.

- When sneezing, shut the mouth and nose with disposable tissue paper; if no tissue paper is available, close the mouth and nose with the inside of the elbow.

- It is preferable to consume raw animal products.

- If we travel and get respiratory problems within 14 days, we should contact our doctor by applying to the nearest medical unit while wearing a mask.

According to BBC News (2021), as of 15 January 2021, the number of cases of COVID-19 virus has exceeded 93 million worldwide, and the number of deaths has exceeded 2 million. In mid-January 2020, the virus's transmission rate increased. Later that year, cases of the virus were reported in a number of countries throughout Europe, North America, and Asia-Pacific (Centres of Disease Control and Prevention, 2021). As of May 9 , 2021 , there were $158,855,657$ confirmed cases in the world, $137,265,667$ recovered cases, while 3,303,946 patients died due to the virus (Worldometers, 2021). At the same time, the number of confirmed cases in Turkey was 15.2 million and the number of deaths was 43,029 (Our World in Data, 2021).

Many countries have begun their first action to curb the spread of the virus by introducing travel restrictions and quarantine measures. During this period, people withdrew to their houses and refused to welcome anyone in, while many institutions, particularly schools, continued to operate mostly over the internet. The global economy has also been badly impacted by this period, which has seen dramatic shifts in individual lifestyles. According to economists, in the global economy, which is experiencing one of the most serious periods of contraction in history, the damage to the economic cycle increases as the measures taken by countries to protect against the pandemic increase. According to International Monetary Fund (IMF) forecasts, the global economy will fall by $3 \%$ in 2020 as a result of the pandemic, a level not seen since the 1930s' "Great Depression" (ATTA, 2020a). As a matter of fact, by the year 2021, we have witnessed that the pandemic continues unabated and that the world is experiencing a historical crisis.

According to the United Nations World Tourism Organization (UNWTO), the COVID-19 pandemic resulted in a $22 \%$ decline in international visitor arrivals in the first quarter of 2020 . The United Nations specialized agency estimates that the situation could result in annual declines of between $60 \%$ and $80 \%$ in comparison to 2019. This imperils the livelihoods of millions of people and threatens to halt progress toward the Sustainable Development Goals (SDGs) (UNWTO, 2020). Travel restrictions were first implemented solely in nations affected by the pandemic, but as the virus spread, travel restrictions were 
broadened internationally and practically all flights were suspended (ATTA, 2020a).

International tourism movements decreased by $81 \%$ in July 2020 and $79 \%$ in August 2020. The average loss in international tourism movements in the first 8 months of 2020 is $70 \%$. The number of international travels decreased by 700 million people when compared to the previous year and the loss of international tourism income is 730 billion dollars (ATTA, 2020a). With the effect of the pandemic, the number of foreign tourists visiting Turkey in the first ten months of 2020 decreased by $72.5 \%$ when compared to the previous period. The number of foreign tourists, which was 40.7 million in 2019, decreased to 11.2 million in 2020. In the first ten months, the top 5 countries that sent tourists to Turkey were Russia, Germany, Bulgaria, Ukraine, and England (ATTA, 2020b).

To restore tourism to its pre-2019 level, it is required to rapidly implement vaccination research throughout the world and thereby build social immunity. Although the virus affects tourism movements so much, vaccination studies have been a promising source of acceleration of tourism movements for many countries, including Turkey.

\subsection{Definition, scope, and classification of cost concept}

There is a close relationship between the concepts of cost and expense, and in the definition of expenses, costs that run out of benefit are mentioned. According to Büyükmirza (2010), cost is the sum of the benefits that must be borne in order to achieve the targeted result. In this definition, since the cost element that does not have monetary value cannot be combined with other cost elements, only costs that have monetary value are taken into account in enterprises. Additionally, the concept of cost is all the sacrifices that are made to achieve a goal or to have an object. According to Akdoğan (2018, p. 11), cost is "the monetary value of the expenses incurred during that period for the acquisition of a good or service and the sacrifices incurred in the acquisition of that good and service from the expenditures made in the previous period". As stated in the definition, cost is the total expenditure incurred directly and indirectly to obtain a good or service where it is used or sold. According to Horngren et al., (2009, p. 53), cost is "defined as the resource sacrificed to achieve a specific goal". The term "cost" refers to the monetary amount required to purchase products or services in this definition.

Expense is defined as spending or consumption to benefit the business (Büyükmirza, 2010). According to Yılmaz (2007), expense is defined as the monetary amount of goods and services used or consumed for the continuation of operating activities or the production of goods or services. The distinction between cost and expense is the time period during which money is spent. The cost of a manufacturing firm is the monetary value of the commodities and services it needs and consumes in the course of production. Additionally, the cost can be stated as a percentage of the expense associated with production. On the other hand, expense refers to the monetary value of goods and services that an enterprise utilizes and consumes over a specified time period in order to continue its operations and existence and create revenue. Here, the cost includes all production charges, whereas the expense includes only a portion of the total cost spent over a specified time period.

Business operations vary according to the industry in which it operates and the type of work it performs. In order for the business to continue its activities, it must perform purchasing, production, research and development, marketing, sales and distribution, general management and financing functions and bear the costs arising from them. Businesses purchase goods and services to be used and sold in their activities, and their expenses for this constitute the cost of the goods and services received (Akdoğan, 2018). Direct labour, direct material supply, and general manufacturing charges are all components of production costs (Haftici, 2009; Usal \& Kurgun, 2006). Elements of production costs are divided into direct labour, direct materials and general production expenses (Haftacl, 2009). Research and development expenditures include costs associated with product design, sample production, and pilot implementation activities necessary to develop a new product or process. Marketing sales and distribution expenses include market research, advertising, sales, and sales development (Büyükmirza, 2010). The finance costs include office services, personnel administration, legal administration, loans and collections, general management costs, and debt, as well as interest, commission, and bank fees associated with the provision of foreign resources to the enterprise (Akdogan, 2018).

Initial material and material expenses incurred by the enterprises for manufacturing can be categorised according to cost type. That is, personnel and pay costs, outsource benefits and services, taxes, fees and charges, depreciation, finance, and other costs. Additionally, there are fixed, variable, semi-fixed, and semivariable expenses (mixed costs) associated with an enterprise's level of activity (Wileman, 2008). The costs incurred by an enterprise even if it does not produce anything are referred to as fixed costs (Akdoğan, 2018). Costs that increase or decrease in the same direction or at the same rate as the volume of production are called variable costs. The raw materials and direct labour costs are included in this group. There are semi-fixed semivariable (mixed) costs that show fixed cost characteristics up to a certain production process and show variable expense characteristics depending on the volume of production (Abdioğlu, 2012). It is also possible to make a separate classification of costs as controllable and uncontrollable costs, as well as standard costs (planned/targeted) and realized costs. Costs are a management function as important as management's responsibilities to provide income.

\subsection{Cost concept in accommodation enterprises}

In the literature, Strielkowski (2020) has identified technology costs, Jiang \& Wen, (2020) cleaning and hygiene costs, Pavlatos et al. (2021) health measures costs and Dayour, Ghana \& Adam 
(2020) room, staff, and management costs. COVID-19 has impacted every sector worldwide, but the hotel industry has been particularly hard hit (Krishnan, Mann, Seitzman \& Wittkamp, 2020). The hotel industry, which requires significant capital and labour, has been particularly hard hit, owing to its high investment and operating costs (Wu, Zhang, Law \& Zheng, 2020). Hotel operation costs include fixed costs (occupancy cost, rent, insurance, interest, fixed salaries and wages, depreciation, franchise fees), variable costs (salaries and wages, advertising and promotion, transportation, energy, room expenses, maintenance-repair, laundry, food and beverages, duty meals, VIP amenities, guest and cleaning supplies, telecommunications, contract charges, income taxes), semivariable costs (electricity, gas, water \& sewer, utility costs), and discretionary costs (major repairs, complimentary, special VIP amenities, etc.) (Andrews, 2007; Dittmer \& Keefe, 2009). Cost structures of hotels can be listed as direct material, raw material, direct labour, overhead and administrative cost, property operations and maintenance, transportation, utility, property insurance, depreciation and amortization, other (Mashayekhi \& Ara, 2017; Jagels \& Coltman, 2004).

In accommodation enterprises, which are in the service sector, cost elements have different characteristics when compared to service production enterprises (Işık, 2016). Looking at the financial statements of accommodation enterprises, certain characteristics are different from other sectors. These features are (Kutlan, 1998):

- Current assets are lower, fixed assets are higher,

- Has a short-term production cycle,

- The inventory item does not occupy much space in the total asset,

- Fixed costs have a lower ratio than variable costs,

- Discount rate on sales is quite low,

- Food and beverage revenues are quite high when compared to other revenues,

- Personnel expenses in accommodation enterprises that are in a labour-intensive sector can reach up to $80 \%$ of the total expense,

- Investment return time is shorter than in other sectors.

Most of the costs in accommodation enterprises are investment expenses. The main costs that accommodation businesses have to bear after they become operational are labour costs, food and beverage costs and accommodation services costs (Türksoy, 2007). Cost elements of accommodation enterprises are examined in two headings: investment costs and operating costs (Yılmaz, 2007). Investment in hospitality is defined as "carrying out the activities that constitute the purpose of the hotel business in satisfactory conditions, supplying capital goods that can be used for more than one year to maintain competitiveness, and purchasing the minimum amount of capital elements that must be in the process to continue the activities without interruption" (Olalı \& Korzay, 1993, p. 93).
Investment costs are the costs incurred from the establishment of the enterprise until the process of its construction and operation. Investment costs are collected in five headings: Land costs, facility costs, investment period interest, operating capital items and other investment costs (Yilmaz, 2007).

Operating costs are examined in two headings: Period costs that have a direct impact on decisions made in the business and the cost of goods and services produced. The costs for the period are related to the entire business, and the goods and services produced are costs that do not directly concern it. Period costs are also called expenses deducted from income at the end of the period (Yilmaz, 2007).

\subsection{Post-coronavirus (COVID-19) costs of accommodation enterprises}

During the COVID-19 period, the tourist industry, which was impacted by travel limitations, plans to gradually lift bans globally following the pandemic. As in the world, flights and hotels in Turkey are planned to become active again in the first stage of the normalization process. In this context, a series of precautions to be followed by hotels in the new normal period Turkey is in have also been explained (Ministry of Culture and Tourism, 2020). However, due to the danger of the pandemic, it is expected that tourism with domestic tourists will be revived in countries first, and short-haul flights will take place, and after the pandemic has completely disappeared, long-haul flights will be made (World Travel and Tourism Council, 2020). The Turkish tourism industry, which hosts approximately 50 million tourists a year (Ministry of Culture and Tourism, 2021a) and employs millions of people, there are concerns that the COVID-19 pandemic will cause major problems in 2021 as in 2020.

Along with the coronavirus, changes in people's lifestyles, holiday perceptions, travel, accommodation, and eating and drinking habits have happened. Each country, in collaboration with the Ministry of Health, has prepared circulars covering tourism, education, industry, and trade, as well as guidelines for compliance. The Turkish Ministry of Culture and Tourism (2020) published the safety measures to be carried out by the activities of tourism accommodation establishments:

- Obligation to obtain a safe tourism certificate,

- Acceptance of guests in accordance with the rules of social distance to enterprises,

- In meeting rooms, lobby areas, dining rooms, etc., guests are welcomed in accordance with the area's social distancing rule.

- Gym, etc. limiting the number of people who will be in the environment at the same time in the areas.

- 1.5 metres of distance between the tables where food is served,

- Acceptance of children in accordance with social distance rules in mini clubs, 
- Medical personnel required to be present at the facility every day of the week,

- Preparation of isolation rooms,

- Thermal camera or non-contact temperature measurement, hand disinfection and disinfection carpets at the entrance to the facility,

- Whenever possible, opting for contactless payment,

- Maintaining a sterilization device, a hygiene barrier, and other necessary hygiene equipment in product shipments and kitchen areas,

- Building a barrier to the guest side in open buffet services and serving staff,

- Possession of disposable products such as sugar, salt, napkins, and spices,

- Providing training to employees working in the enterprise about the epidemic and hygiene,

- Personnel should wear personal protective equipment such as masks, gloves, and visors and should regularly clean their hands,

- Frequent cleaning of surfaces with heavy hand contact, such as door handles, elevator buttons, POS device phone, faucet batteries, room card, towel card,

- Maintaining and sterilizing tools and equipment, such as dishwashers, ventilation systems, and air conditioning systems,

- Ensuring disinfection of all surfaces contacted by hand in guest rooms and using disposable boucle materials,

- Continuous ventilation of indoor areas such as lobby and room,

- Ensuring the cleanliness and hygiene of the areas where food and beverage service is prepared regularly,

- Frequent cleaning of surfaces in Mini clubs and playgrounds with detergent water,

- Information and landmarks suitable for social distance in lobby, dining hall, elevator, and meeting rooms,

- Spa units operate in accordance with the principles established during the normalization process,

- Distribution of beach towels by staff in sealed bags.

\section{Method}

During the covid-19 pandemic, people's quality of life has decreased, and their vital risks have increased. People's holiday needs and desires have increased against this pandemic, which causes psychological problems for people. People will need safe enterprises to stay in during their holidays. On the other hand, occupancy rates and revenues of accommodation businesses fell significantly during the pandemic. There are costs that accommodation enterprises incur to ensure that guests and staff can continue to provide services while maintaining their health. In this context, "costs of COVID-19 to accommodation enterprises" is the main problem of this study.

In this study, qualitative research method was used. The qualitative research method is a method that interprets the research problem and adopts an interdisciplinary holistic perspective (Altunışık, Coşkun, Bayraktaroğlu \& Yıldırım, 2010). As data collection technique, interview technique from qualitative research methods was used. The purpose of this research is to determine whether Coronavirus (COVID-19) imposes additional costs on accommodation enterprises and to quantify those costs. In this context, hotel managers evaluate 2020 operating budgets, occupancy rates, profitability, the decision of businesses to remain open or close during the pandemic period, and expectations for the following year.

The universe of the study is comprised of 4-5-star accommodation enterprises in Antalya city, Turkey. There are a total of 534 hotels in Antalya (ACCl, 2019), and 75 4-5-star hotels in Antalya's Kemer city (http://www.kemer.gov.tr, 2021a). The sample of the research is $104-5$-star hotel managers in Kemer tourism area of Antalya. A simple random sampling method was used to determine the sample. In a simple random sampling method, each unit has an equal probability of being selected independently of each other (Ural \& Kılıç, 2005). 10 hotel managers were interviewed using a semi-structured interview form in hotel enterprises determined by a simple random sampling method. Interviews with managers were conducted by phone and face-to-face (in accordance with covid-19 measures) for an average of 40 minutes between 04.10.2020 and 29.11.2020 and recorded by taking notes.

Frequency analysis was carried out on the demographic data of hotel managers obtained from the interview and the characteristics of the enterprises. The responses of hotel managers to questions were analysed for content and word cloud analysis with the MAXQDA Analytics Pro program.

\subsection{Data collection}

10 valid forms applied by semi-structured interview technique were accepted in enterprises determined by simple random sampling method. The semi-structured interview technique is more flexible than the structured interview, and the number and order of questions can also vary depending on the environment (Kozak, 2018). Table 1 contains interview questions prepared for a semi-structured interview. 
Table 1 - Questions asked in the interview

\begin{tabular}{|l|l|}
\hline Q 1. & How has the COVID-19 period affected your enterprise? \\
\hline Q 2. & How have your enterprise's occupancy rates changed? \\
\hline Q 3. & How has this COVID-19 period affected your enterprise financially? \\
\hline Q 4. & What are the costs of running your enterprise with incomplete capacity due to COVID-19? \\
\hline Q 5. & What is the impact of COVID-19 on the costs of improving health conditions of your enterprise? \\
\hline Q 6. & What is the impact of COVID-19 on costs for technological innovations in your enterprise? \\
\hline Q 7. & What is the impact of COVID-19 on personnel costs in your enterprise? \\
\hline Q 8. & What is the impact of COVID-19 on cleaning costs in your enterprise? \\
\hline Q 9. & What is the cost of obtaining the Safe Tourism Certificate for the enterprise due to COVID-19? \\
\hline Q 10. & What is the impact of COVID-19 on other costs in your enterprise? \\
\hline Q 11. & $\begin{array}{l}\text { Did you get the expected profit for the business when you opened the hotel when you examined these costs } \\
\text { incurred during this season? }\end{array}$ \\
\hline Q 12. & $\begin{array}{l}\text { If COVID-19 continues, how did you plan for subsequent processes in terms of financial items and what } \\
\text { measures did you take for the enterprise? }\end{array}$ \\
\hline Q 13. & If this pandemic continues, can I find out about your decision to open your hotel in the next 2021 season? \\
\hline
\end{tabular}

\subsection{Data analysis}

Information about interviews, demographic characteristics of the managers interviewed and characteristics of the businesses in which the managers work are given in Table 2, Table 3, and
Table 4, together with the percentage and frequency distribution. Frequency distribution is a type of analysis for calculating repetitive expressions or Numbers within the obtained data. In this type of analysis, the goal is to determine the frequency of expressions in the data (Saldamlı \& Can, 2019).

Table 2 - Interview information

\begin{tabular}{|l|c|c|c|}
\hline & Interview Date & Interview Time & Length of Interview \\
\hline Participant 1 & 23.11 .2020 & 15.30 & 40 minutes \\
\hline Participant 2 & 23.11 .2020 & 15.00 & 30 minutes \\
\hline Participant 3 & 04.10 .2020 & 18.00 & 60 minutes \\
\hline Participant 4 & 06.10 .2020 & 12.20 & 35 minutes \\
\hline Participant 5 & 23.11 .2020 & 17.10 & 30 minutes \\
\hline Participant 6 & 20.11 .2020 & 17.00 & 45 minutes \\
\hline Participant 7 & 20.11 .2020 & 10.00 & 30 minutes \\
\hline Participant 8 & 18.11 .2020 & 13.00 & 40 minutes \\
\hline Participant 9 & 29.11 .2020 & 14.15 & 45 minutes \\
\hline Participant 10 & 01.11 .2020 & 11.00 & 50 minutes \\
\hline
\end{tabular}

\section{Results}

\subsection{Findings}

Table 3 contains data on the demographic characteristics of hotel managers. $90 \%$ of managers' survey respondents are male, $10 \%$ are female, $60 \%$ are single, and $40 \%$ are married. When the managers' educational backgrounds are examined,
$10 \%$ are high school graduates, $60 \%$ are undergraduates, and $30 \%$ are graduate students. It is evident that the managers at the hotels that participated in the study have a high level of education. Finally, $50 \%$ of the managers are at the age of $18-25$, $20 \%$ at $25-34$ and $30 \%$ at $34-50$. Managers participating in the research in Kemer, Antalya consist of young people.

Table 3 - Demographics of hotel managers

\begin{tabular}{|l|c|c|}
\hline \multicolumn{1}{|c|}{ Profile } & Frequency & $\%$ \\
\hline Sex & 1 & $10 \%$ \\
\hline Male & 9 & $90 \%$ \\
\hline Female & 10 & $100 \%$ \\
\hline Total & & $40 \%$ \\
\hline Marital Status & 4 & $60 \%$ \\
\hline Married & 6 & $100 \%$ \\
\hline Single & 10 & $10 \%$ \\
\hline Total & & $60 \%$ \\
\hline Education & 1 & $30 \%$ \\
\hline High school & 6 & $100 \%$ \\
\hline Bachelor & 3 & \\
\hline Graduate & 10 & $50 \%$ \\
\hline Total & & $20 \%$ \\
\hline Age & 5 & $30 \%$ \\
\hline $18-25$ & 2 & $100 \%$ \\
\hline $26-34$ & 3 & \\
\hline $35-50$ & 10 & \\
\hline Total & & \\
\hline
\end{tabular}


According to Table 4, 40\% of the managers of the hotels surveyed are top-level managers, $30 \%$ are middle-level managers and $30 \%$ are lower-level managers. In terms of the number of stars of enterprises, $20 \%$ are 4 -star hotels and $80 \%$ are 5 -star hotels. $60 \%$ of the operating period of enterprises is between $1-10$ years, $20 \%$ is between $11-20$ years and $20 \%$ is between 21 years and above. $20 \%$ of the number of employees working in the enterprise is between $1-100$ people, $30 \%$ is between $101-250$ people, and $50 \%$ is between 251 people and above.

Table 4 - Profile of the hotels

\begin{tabular}{|l|c|c|}
\hline \multicolumn{1}{|c|}{ Profile } & Frequency & $\%$ \\
\hline Administrative level & & $40 \%$ \\
\hline Top-level manager & 4 & $30 \%$ \\
\hline Mid-level manager & 3 & $30 \%$ \\
\hline Lower-level manager & 3 & $100 \%$ \\
\hline Total & 300 & $20 \%$ \\
\hline Stars of hotel & & $80 \%$ \\
\hline 4 Stars & 2 & $100 \%$ \\
\hline 5 Stars & 8 & \\
\hline Total & 10 & $60 \%$ \\
\hline Operation period of the business & & $20 \%$ \\
\hline $1-10$ years & 6 & $20 \%$ \\
\hline $11-20$ years & 2 & $100 \%$ \\
\hline 21 years and over & 2 & \\
\hline Total & 10 & $20 \%$ \\
\hline Number of Employees & & $30 \%$ \\
\hline $1-100$ & 2 & $50 \%$ \\
\hline $101-250$ & 3 & $100 \%$ \\
\hline 251 and over & 5 & \\
\hline Total & 10 & \\
\hline
\end{tabular}

In Table 5 below, the participants' answers to the questions are included in the semi-structured interview form. In the research, the interview forms obtained from the managers are examined one by one and the common opinions are summarized in the table below. The questions are given in order in the Table 1.

Table 5 - Participants' answers to questions

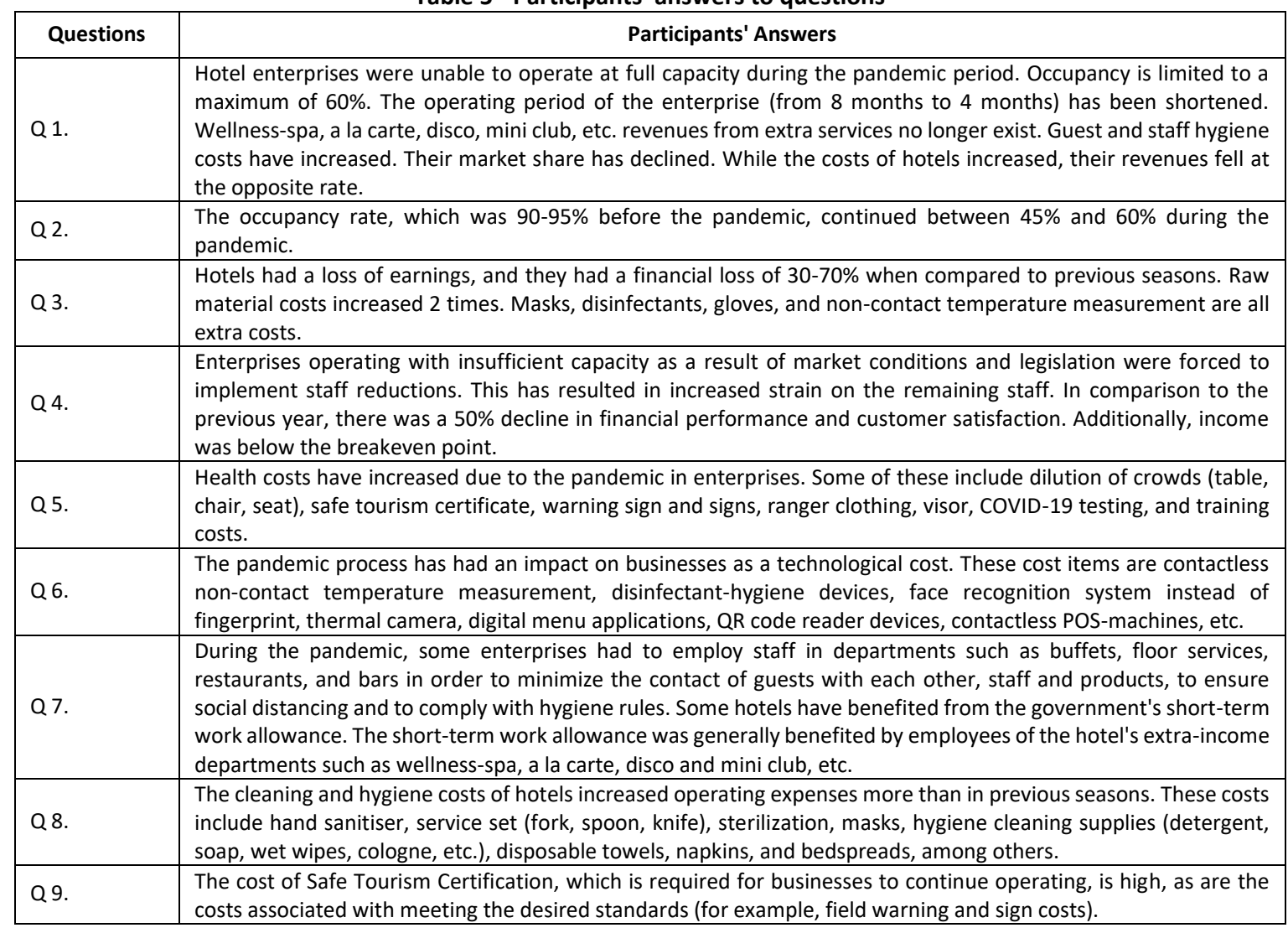




\begin{tabular}{|l|l|}
\hline \multicolumn{1}{|c|}{ Questions } & \multicolumn{1}{c|}{ Participants' Answers } \\
\hline Q 10. & $\begin{array}{l}\text { Capacity reductions in food and beverage areas and buffets have resulted in additional costs for businesses. During } \\
\text { the pandemic period, additional revenue streams such as a la carte restaurants, banquette seating, and meetings } \\
\text { are no longer available. Efforts to protect the health of employees and customers are accounted for as a cost in } \\
\text { the enterprise's financial statements. }\end{array}$ \\
\hline Q 11. & $\begin{array}{l}\text { The expected profits were not achieved in the enterprises. Restriction on occupancy rate (max. 60\%), personnel } \\
\text { costs, and head-to-head competition. While revenue was lower than budgeted, costs exceeded budgeted levels. }\end{array}$ \\
\hline Q 12. & $\begin{array}{l}\text { Hotel enterprises and staff have adapted to this pandemic period. Hotels plan to work with more local agents and } \\
\text { individual tourists in the following seasons. Hotels are also considering buying the products they need in advance, } \\
\text { saving energy and improving staff productivity. }\end{array}$ \\
\hline Q 13. & $\begin{array}{l}\text { Enterprises will continue their activities in the 2021 season by taking the necessary measures. The government is } \\
\text { considering opening hotels based on incentives (e.g., tax deferral, short work allowance for staff), mandatory } \\
\text { measures, travel restrictions, booking rate. }\end{array}$ \\
\hline
\end{tabular}

According to the responses given by the hotel managers (see Table 1 and Table 5), the findings obtained are as follows:

- Hotel enterprises operated at a maximum occupancy rate of $60 \%$ during the pandemic period. In hotels that normally operate for 8 months of a year, this period has decreased to 4 months.

- Sales and profitability also decreased due to low occupancy rates of hotels. Especially the leisure and entertainment departments of Hotels (Spa, wellness, Turkish bath, massage, Disco, club, etc.) remained closed during the pandemic period.

- Cash inflows of hotels decreased when compared to before the pandemic, so there was a decline of up to $70 \%$ in their financial structure.

- Due to the short operating period and low occupancy rates, layoffs in hotel enterprises have reached up to $50 \%$. In parallel with the lack of staff, there was also a decrease in customer satisfaction at the same rate.

- Social distance, mask and hygiene rules have imposed extra cleaning, health, safety, technology, and staff costs on hotels. These costs have increased by $200 \%$ when compared to before the pandemic period.
- Hotels must incur costs in order to obtain a governmentissued "Safe Tourism Certificate" and to comply with the measures outlined in this document.

- Throughout the pandemic period, hotels made an effort to keep stock levels to a minimum. They attempted to keep non-emergency repair and maintenance investment costs and expenditures to a minimum, but instead focused on energy conservation (e.g., air conditioning, heating, lighting, water).

- Efficiency has fallen in almost every area of hotel enterprises.

- The government's incentives and grants to enterprises (such as short work allowances, deferrals of taxes and insurance premiums) were insufficient.

In the research, word cloud analysis was performed with MAXQDA Analytics Pro 2020 (trial) qualitative data analysis program. Figure 1 provides a word cloud of 50 words that passes at least 10 times out of the 4,290 words found in interview forms with managers. When creating a word cloud; "and, but, like, with, even, well, for example, until, however, how, why" words are not included in the analysis. This word cloud provides (testing) the feedback of hotel managers obtained from tape recordings.

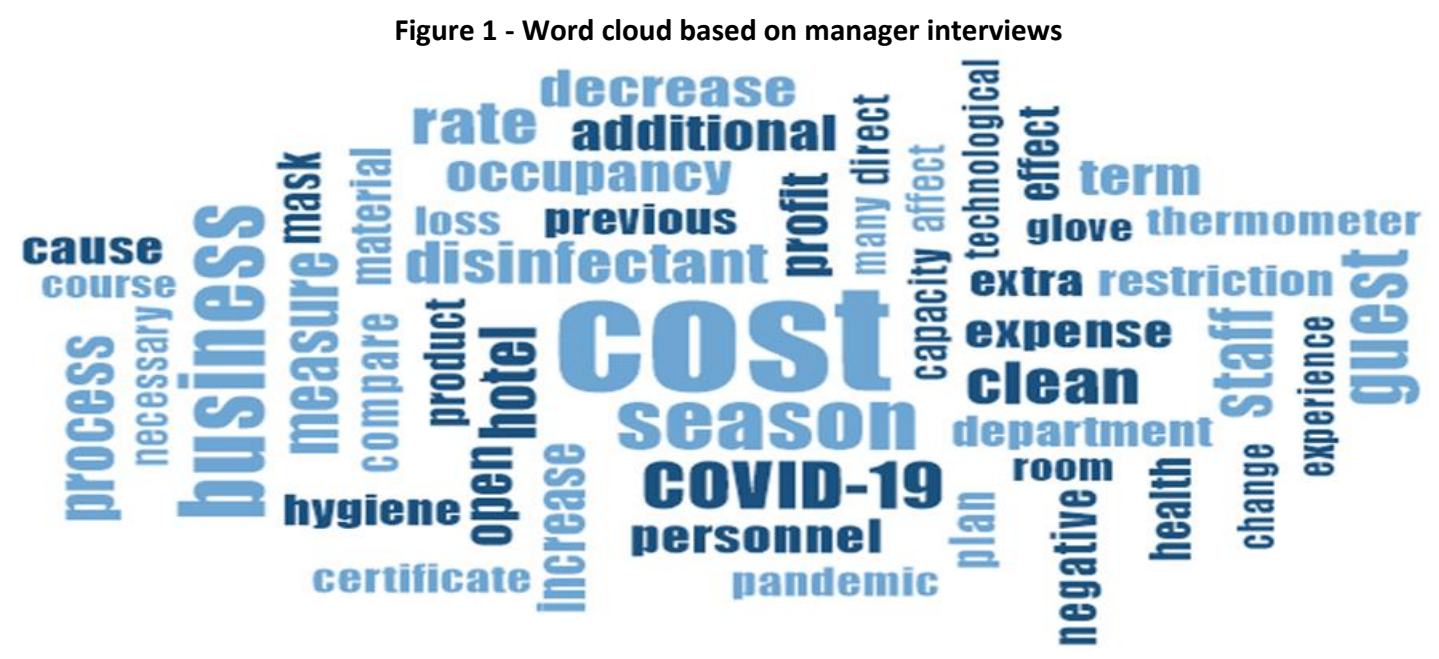

Words such as "cost, pandemic, COVID-19, business, restriction, term, effect, affect, season, staff, many, measure, necessary, course, cause, plan, loss, negative" in the word cloud in Figure 1 highlight the impact of the pandemic. Various costs are 
understood from words obtained from the word cloud such as "disinfectant, hygiene, mask, glove, thermometer, certificate, clean". Words such as "rate, occupancy, profit, expense, room, department, extra, profit, increase, open, product, capacity, additional, direct" emphasize the economic impact of the pandemic on hotel enterprises.

\subsection{Discussion}

COVID-19 has emerged from the safety and health measures cost, hygiene and cleaning cost, technological tools cost of hotels (See table 6).

Table 6 - Operating costs emerging in hotels with COVID-19

\begin{tabular}{|l|l|l|}
\hline \multicolumn{1}{|c|}{ Safety and health measures cost } & \multicolumn{1}{|c|}{ Hygiene and cleaning cost } & \multicolumn{1}{|c|}{ Technological tools cost } \\
\hline Certificate of safe tourism & Disinfectant & Digital menu applications \\
\hline Safety in buffets & Gloves & QR code readers \\
\hline Covid-19 tests and educations & $\begin{array}{l}\text { Disposable material (towel, paper } \\
\text { cup, plastic spoon) }\end{array}$ & $\begin{array}{l}\text { Non-contact temperature } \\
\text { measurement }\end{array}$ \\
\hline Face shield & Cologne, Soap & Hygiene machine \\
\hline Avoidance of crowds & Wet wipe, napkin & Thermal camera \\
\hline Landmarks, warming sings & $\begin{array}{l}\text { Extra cleaning (rooms, corridor, } \\
\text { restaurant) }\end{array}$ & Disinfectant machine \\
\hline Protective clothes & Using sterilized cutlery & $\begin{array}{l}\text { Face reading system instead of } \\
\text { fingerprint }\end{array}$ \\
\hline
\end{tabular}

COVID-19 has forced hotel businesses to look closely at their spending to see where they might have opportunities to cut costs in the pandemic environment. The costs listed in the table increased with the pandemic due to reduced hotel occupancy rates or even long-term closures of hotels, resulting in new costs such as safe health certificates, hand contactless technologies. In addition, in order to promote that the hotel room is safe and sanitary, the rooms need to be redesigned to have fewer contact points. From remote controls and light switches to doorknobs and glassware, hotels are likely to shape the customer experience in such a way that these and other items in guest rooms and public spaces are not touched. Hoteliers will be encouraged to invest in innovative technologies that reduce these touchpoints, such as the use of digital keys, digital payments via mobile phone, and menu replacement with QR codes, as a result of a cultural shift. F \& B establishments will almost certainly adopt social distancing practices in their neighbourhoods, redesign the "traditional" full-service restaurant experience, and leverage advanced forecasting tools to avoid food oversupply and staff redundancy.

Promotional trips and field visits by travel agencies can be partially replaced with virtual tours to maintain social distance and reduce hotel costs. Hoteliers will be critical in creatively attracting groups to their properties without spending lots of money. For instance, hotel sales managers may be encouraged to offer lower-cost concessions to travel agents, such as complimentary upgrades or meeting planner signing bonuses, that have a negligible impact on profits. While sales and marketing expenses are inherently variable, hoteliers may find themselves needing to cut them. Many consider the hotel's operating engines to be the rooms, food and beverage, and sales and marketing. These departments will need to adapt by evolving their applications and altering their fixed costs in order to be more connected to business volume. Another effect of covid-19 on hotel costs is that fixed costs need to be taken into account in the future. Additionally, increased outsourcing will continue to be a factor pushing hotels. Forecasting tools will become more critical as hoteliers improve their ability to forecast occupancy levels and demand for their services. As hoteliers reinvent industry best practices, lateral thinking will become the "new norm."

\section{Conclusion}

After the COVID-19 pandemic, which affected the world, people who were forced to stay in quarantine in their homes began to make travel and vacation plans, provided that they followed social distance, masks and hygiene rules to meet their needs for a vacation. In Turkey, most enterprises closed the 2020 holiday season and prepared for 2021, while some enterprises followed the rules and opened for the 2020 season despite the pandemic.

The COVID-19 pandemic negatively affected almost all sectors as well as the accommodation sector. Hotel enterprises have had to contend with increased costs across the board during this pandemic period. Hotels had to accept customers at a maximum occupancy rate of $50 \%$ due to the social distance requirements. As a result of the staff presenting the hotels' open buffets, additional staff was required, new arrangements were made in staff areas to ensure hygienic conditions, rooms were converted to use disposable materials, and enterprises were required to obtain a safe tourism certificate. Additionally, legal restrictions have reduced the tourism season in hotel businesses from eight to four months. Business occupancy rates remained between 45-60 per cent. There was also a $60 \%$ negative deviation in the enterprises' budget targets. Hotel managers were more concerned with achieving breakeven, retaining staff, and maintaining the hotel's image than with achieving the expected profit. The major types of hotels they have to endure the costs are as follows: Safe tourism certification, thermal cameras, sterile materials, non-contact temperature measurement, masks, gloves, visors, protective clothing, disinfectants, cleaning supplies, medical supplies, and 
extra personnel are incurred. As a matter of fact, it was observed that cleaning and health material costs increased by $200 \%$ compared to previous periods. According to the findings, fixed and variable costs of hotels (e.g., cleaning, room, technology, management, and staff) increased due to COVID19 , while the occupancy rate limit (maximum 60\%) caused cancellations and loss of revenue. These findings support previous research in hotel operating cost (e.g., Pavlatos, Kostakis \& Digkas, 2021; Hameed, Mahomed, \& Carvalho, 2021; Milovanovic, 2021). Kaushal \& Srivastava (2020) also highlighted the difficulty of managing high fixed costs in response to reduced business volumes of hotels that are sensitive to shocks and instability.

This paper makes the following contributions to current research: To begin, it discusses the additional operating costs (costs associated with safety and health measures, hygiene and cleaning, and technical tools) that arise in hotel businesses. In the event of a crisis, managers can estimate operating costs. Second, it emphasizes the importance of state assistance (tax, SSI, and short-term work allowance) during times of crisis. Thirdly, this paper contributes to the sparse empirical literature. Finally, this article represents one of the first academic studies to examine the operating costs of hotels in Turkey.

This research may have some managerial implications for hospitality executives. After the pandemic, hotel enterprises will need to follow market conditions and customer behaviour much more closely at the beginning of the considerations that they should take into account. For this reason, hotel managers should pay much more attention to cooperation with destination managers. During the pandemic period, enterprises took advantage of new technologies, especially communication, booking, virtual trips, training, virtual shopping, and digital payment methods. Therefore, adapting to new technologies in the future will play a vital role for enterprises. Enterprises will need to devote much more time to crisis management strategies and focus on in-business training on this issue. For crises, enterprises will also need to strengthen their capital structures, track asset and debt ratios, and actively use private reserves and reserve accounts against force majeure in their capital, except for legal reserves. The safe tourism certificate issued by the government to enterprises should be permanent, so that health and hygiene rules should also be mandatory in enterprises. It is necessary to make it compulsory to have health cabins, nurses and/or doctors in enterprises and to make urgent investments in this area. Staff must be trained in flexible working, flexible booking, flexible sales and marketing and be applied when necessary. For international travel and accommodation, the latest health information (for example, a vaccination card or passport) should be available. Close contact with people in enterprises should be minimized and hygiene rules should be tightened further. For example, by retinal scanning instead of fingerprinting, entry and exit systems can be converted into enterprises. There is only one thing that crises provide to enterprises: it is experience. This pandemic has taught people and businesses a lot. It is important not to forget these things and be prepared for the next time.

Thus far, pandemics, natural disasters, economic crises, and other crises are all likely to have a negative effect on tourism in the future. Safe Tourism Certification, COVID-19 vaccine studies, and vaccination are critical steps in reversing the pandemic's course. The World Health Organization, government officials, tourism businesses, and tourists have been tasked with critical tasks in the fight against the pandemic. Subsequent studies can examine the satisfaction of tourists who have been subjected to numerous measures and restrictions. The impact on the costs of non-hotel tourism businesses (such as food and beverage, travel, transportation, entertainment, and recreation) can be examined.

\section{References}

Abdioğlu, H. (2012). Cost accounting. Balıkesir: Dora Yayınları.

ACCI (Antalya Chamber of Commerce and Industry (2019), Antalya ecomomy: Fact and figures. Retrieved from http://www.atso.org.tr/yukleme/dosya/6cf973e5fa33c5843fd357300a $01 \mathrm{e} 6 \mathrm{c} 4$.

Akdoğan, N. (2018). Cost accounting applications. Ankara: Gazi Kitabevi. Altunışık, R., Coşkun, R., Bayraktaroğlu, S., \& Yıldııım, E. (2010). Research methods in social sciences Spss applied. Sakarya: Sakarya Yayıncllık.

Andrews, S. (2007). Hotel housekeeping management and operations. New Delphi, India: Tata McGraw Hill Publishing.

ATTA (Association of Turkish Travel Agencies) (2020a). Assessment of Turkey and world tourism in the Covid-19 Process. Retrieved from https://TÜRSAB.org.tr/apps//Files/Content/6ad52b35- 1dd2-41c29f1c-c24cc19e7a63.pdf

ATTA (Association of Turkish Travel Agencies) (2020b). What kind of world awaits us after coronavirus (COVID-19)? Retrieved from https://TÜRSAB.org.tr/apps//Files/Content/8b368379-712e4ca38425-69ae28b9f113.pdf.

BBC NEWS (2021). Covid-19: The number of people who died as a result of illness in the world has exceeded 3 million, what is the latest situation in countries? Retrieved from https://www.bbc.com/turkce/haberlerdunya-51719684.

Brouder, P. (2020). Reset redux: Possible evolutionary pathways towards the transformation of tourism in a Covid-19 world. Tourism Geographies, 22(3), 1-7.

Büyükmirza, K. (2010). Cost and management accounting. Ankara: Gazi Kitabevi.

Centers of Disease Control and Prevention (CDC) (2021). Confirmed Covid-19 cases globally. Retrieved from https://web.archive.org/web/20200220052906/https:/www.cdc.gov/c oronavirus/2019-ncov/locations-confirmed-cases.html\#map.

Dayour, F., Ghana, V. \& Adam, I. (2020). Managing the COVID-19 crisis: coping and post-recovery strategies for hospitality and tourism businesses in Ghana. Journal of Hospitality and Tourism Insight, 4(1), 1-20.

Dittmer, P. R. \& Keefe, D. J. (2009). Principles of food, beverage, and labor cost controls. Huboken, New Jersey: John Wiley \& Sons, Inc.

Gallego, I. \& Font, X. (2020). Changes in air passenger demand as a result of the Covid-19 crisis: Using big data to inform tourism policy. Journal of Sustainable Tourism, 29(9), 1470-1489.

Galvani, A., Lew, A., \& Perez, M. S. (2020). Covid-19 is expanding global consciousness and the sustainability of travel and tourism, Tourism Geographies, 22(3), 567-576. 
Gössling, S., Scott, D., \& Hall, M.C. (2021). Pandemics, tourism and global change: A rapid assessment of covid-19, Journal of Sustainable Tourism, 29(1), 1-20.

Gretzel, U., Fuchs, M., Baggio, R., Hoepken, W., Law, R., Neidhardt, J., \& Xiang, Z. (2020). E-Tourism beyond covid-19: A call for transformative research. Information Technology \& Tourism, 22, 187-203.

Haftacı, V. (2009). Cost accounting. Kocaeli: Umuttepe Yayınları.

Hall, M. C., Scott, D., \& Gössling, S. (2020). Pandemics, transformations and tourism: Be careful what you wish for. Tourism Geographies, 22(3), 577-598

Hameed, N., Mahomed, R. \& Carvalho, I. (2021) Measures to be implemented in the hotel buffets during the COVID-19 pandemic, Anatolia, 32:1, 172-175.

Horngren, C. T., Datar, S. M., Foster. G., Rajan, M. \& Ittner, C. (2009). Cost accounting: A managerial emphasis (13 ${ }^{\text {th }}$ ed.). Upper Saddle River, NJ: Pearson Prentice Hall.

Jagels, M. G. \& Coltman, M. (2004). Hospitality management accounting. New Jersey: John Wiley \& Sons, Inc.

Jiang, Y. \& Wen, J. (2020). Effects of Covid-19 on hotel marketing and management: a perspective article. International Journal of Contemporary Hospitality Management, 32(8), 2563-2573.

loannides, D., \& Gyimóthy, S. (2020). The Covid-19 crisis as an opportunity for escaping the unsustainable global tourism path. Tourism Geographies, 22(3), 624-632.

Işık, I. (2016). Konaklama işletmelerinde yiyecek içecek maliyet kontrolü ve Çanakkale ilinde bir uygulama. Master Thesis, Çanakkale Onsekiz Mart Üniversitesi, Çanakkale.

Kaushal, V. \& Srivastava, S. (2020). Hospitality and tourism industry amid COVID-19 pandemic: perspectives on challenges and learnings from India, International Journal of Hospitality Management, 92(117), 312-321. Doi: 10.1016/j.ijhm.2020.102707,

Kozak, M. (2018), Scientific research: Design, writing and publishing techniques. Detay Yayıncılık, Ankara.

Krishnan, V., Mann, R., Seitzman, N. \& Wittkamp, N. (2020). Hospitality and Covid-19: How long until 'no vacancy' for US hotels? Retrieved from https://www.mckinsey.com/ industries/travel-logistics-andinfrastructure/our-insights/.

Kutlan, S. (1998). Cost controlling and application in 5-star accommodation businesses. İstanbul: Alfa Yayınları.

Mashayekhi, B. \& Ara, M. (2017). Activity-based costing in the hospitality industry: a case study in a hotel. International Journal of Social and Business Sciences, 11(9), 2254- 2258.

Milovanovic, V. (2021). The COVID-19 pandemic effects on the hotel industry, Conference of the tourism challenges amid COVID-19, (TISC 2021, Serbia) - Thematic proceedings, p. 570-587.

Ministry of Culture and Tourism of Turkey (2020). Controlled normalization process circular in accommodation facilities. Retrieved from https://www.ktb.gov.tr/TR261956/konaklamatesislerindekontrollunormallesmesureci-genelg.html.

Ministry of Culture and Tourism (2021a). Tourism information office. Retrieved from http://www.kemer.gov.tr/turizm-danisma-burosu.

Ministry of Culture and Tourism (2021b). Tourism statistics. Retrieved from https://yigm.ktb.gov.tr/TR-9851/turizm-istatistikleri.html.

Ministry of Health (2021). What is Covid-19? Retrieved from https://covid19bilgi.saglik.gov.tr/tr/covid-19-yeni-koronavirushastaliginedir.

Our World in Data. (2021). Coronavirus pandemic (Covid-19). Retrieved from https://ourworldindata.org/coronavirus.

Olalı, H. \& Korzay, M. (1993). Hotel management. İstanbul: Beta Basım Yayın.

Patiar, A. (2016). Costs allocation practices: Evidence of hotels in Australia, Journal of Hospitality and Tourism Management, 26, 1-8.
Pavlatos, O., Kostakis, H., \& Digkas, D. (2021). Crisis management in the Greek hotel industry in response to Covid-19 pandemic. Anatolia, 32(1), 80-92.

Saldamlı, A. \& Can, İ. I. (2019). Scientific research and presentation techniques. Ankara: Detay Yayıncılık.

Strielkowski, W. (2020). International tourism and Covid-19: Recovery strategies for tourism organisations. Preprints, Doi:10.20944/preprints202003, Retrieved from https://www.preprints.org/manuscript/202003.0445.

Türksoy, A. (2007). Factors leading to financial failure in accommodation businesses. Ege Economic Overview / Ege Academic Review, 7(1), 99-115.

UNWTO (United Nations World Tourism Organization) (2021). International tourist numbers could fall $60-80 \%$ In 2020 . Retrieved from https://www.unwto.org/news/COVID-19-international-touristnumbers-could-fall-60-80-in-2020.

Ural, A. \& Kılıç, İ. (2005). Scientific research process and data analysis with Spss. Ankara: Detay Yayıncılık.

Usal, A. \& Kurgun, O. A. (2006). Cost analysis in tourism businesses. Ankara: Detay Yayıncılık.

Wileman, A. (2008). Driving down costs - How to manage and cut costs intelligently. London: Nicholas Brealey.

Worldometer (2021). Coronavirus Toll: Cases \& deaths by country, historical data chart. Retrieved from https://www.worldometers.info/coronavirus/?utm_campaign =homeAdvegas 1 ?

World Travel and Tourism Council (WTTC) (2020). WTTC Outlines What "The New Normal" Will Look Like as We Start to Travel. Retrieved from https://wttc.org/News-Article/WTTC-outlines-what-the-new-normalwillook-like-as-we-start-to-travel.

Wu, F., Zhang, O., Law, R., \& Zheng, T. (2020). Fluctuations in Hong Kong hotel industry room rates under the 2019 novel coronavirus (Covid-19) outbreak: evidence from big data on OTA channels. Sustainability, 12, 7709; Doi:10.3390/su12187709.

Yılmaz, Y. (2007). Food and beverage cost control in hospitality businesses. Ankara: Detay Publishing. 